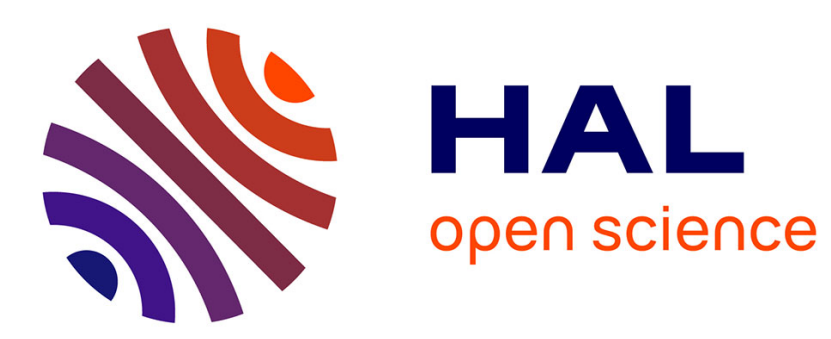

\title{
Porosity of [i] Lactococcus lactis[/i] subsp. [i]lactis[/i] LD61 colonies immobilised in model cheese
} Juliane Floury, Sophie Jeanson, Marie-Noelle Madec, Sylvie Lortal

\section{To cite this version:}

Juliane Floury, Sophie Jeanson, Marie-Noelle Madec, Sylvie Lortal. Porosity of [i]Lactococcus lactis[/i] subsp. [i]lactis[/i] LD61 colonies immobilised in model cheese. International Journal of Food Microbiology, 2013, 163 (2-3), pp.64-70. 10.1016/j.ijfoodmicro.2013.02.014 . hal-01209413

\section{HAL Id: hal-01209413 https://hal.science/hal-01209413}

Submitted on 29 May 2020

HAL is a multi-disciplinary open access archive for the deposit and dissemination of scientific research documents, whether they are published or not. The documents may come from teaching and research institutions in France or abroad, or from public or private research centers.
L'archive ouverte pluridisciplinaire HAL, est destinée au dépôt et à la diffusion de documents scientifiques de niveau recherche, publiés ou non, émanant des établissements d'enseignement et de recherche français ou étrangers, des laboratoires publics ou privés. 


\title{
Porosity of Lactococcus lactis subsp. lactis LD61 colonies immobilised in model cheese
}

\author{
J. Floury ${ }^{\text {a,b,c,* }}$, S. Jeanson ${ }^{\text {a,b }}$, M.-N. Madec ${ }^{\text {a,b }}$, S. Lortal ${ }^{\text {a,b }}$ \\ a INRA, UMR1253 Science et Technologie du Lait et de l'EFuf, F-35042 Rennes, France \\ ${ }^{\mathrm{b}}$ Agrocampus Ouest, UMR1253 Science et Technologie du Lait et de l'Euf, F-35042 Rennes, France \\ c Université Européenne de Bretagne, France
}

\section{A R T I C L E I N F O}

\section{Article history:}

Received 13 July 2012

Received in revised form 19 February 2013

Accepted 23 February 2013

Available online 1 March 2013

\section{Keywords:}

Bacterial colonies

Lactoccocus lactis

Cheese

Confocal microscopy

Diffusion

\begin{abstract}
A B S T R A C T
During cheese ripening, micro-organisms grow as immobilised colonies, metabolising substrates present in the matrix which generate products triggered by enzymatic reactions. Local limitation rates of diffusion, either in the matrix or within the bacterial colonies, can be responsible for modulation in the metabolic and enzymatic activities of micro-organisms during ripening. How bacterial colonies immobilised in cheese are porous to these diffusing solutes has never been explored. The objective of this study was to determine if fluorescent dextrans of different sizes $(4.4,70$ and $155 \mathrm{kDa})$ are able to penetrate through colonies of Lactococcus lactis LD61 immobilised in solid media, either agar or model cheese. Confocal microscopic observations showed that lactococcus colonies immobilised in these two media were porous to dextrans from $4 \mathrm{kDa}$ to $155 \mathrm{kDa}$. However, the rate of diffusion of the solutes was faster inside the colonies immobilised in ultrafiltered-cheese than in agar when large dextrans were considered $(\geq 70 \mathrm{kDa})$. The colonial shape of the lactococcus strain was also shown to be lenticular in agar and spherical in the model cheese, indicating that the physical pressure exerted on the colony by the surrounding casein network was probably isotropous in the UF-cheese but not in agar. In both cases, the fact that lactococcus colonies immobilised in solid media are porous to large dextran solutes suggests that substrates or enzymes are likely also to be able to migrate inside the colonies during cheese ripening.
\end{abstract}

(c) 2013 Elsevier B.V. All rights reserved.

\section{Introduction}

During cheese making, regardless of the cheese type, bacteria are immobilised in the curd during the coagulation step, and grow as colonies spread within the cheese curd. Lactococcus lactis is commonly used as a starter bacterium in the manufacture of different dairy products such as cheese. This bacterium is also generally considered as a model for metabolism regulation, physiology, and genetic studies in Lactic acid bacteria (LAB) (Raynaud et al., 2005). However, interpretation has always been limited by the lack of knowledge regarding in situ bacterial physiology. Technological properties (e.g. acidification, proteolytic or lipolytic activity, and bacteriocin production) can easily be shown and quantified in vitro, but physiological expression within a complex solid matrix was much less explored. Cretenet et al. (2011) published the first in situ global gene expression profile of $L$. lactis in cheeses made from milk concentrated by ultrafiltration (UF-cheeses). The metabolic activity of $L$. lactis colonies immobilised in UF-cheeses was maintained for 7 days and could quantitatively rely on an efficient proteolytic activity. Moreover, the genome analysis revealed multiple strategies of

\footnotetext{
* Corresponding author at: Agrocampus Ouest, UMR1253 Science et Technologie du Lait et de l'Euf, F-35042 Rennes, France. Tel.: + 332234854 52; fax: + 33223485578.

E-mail address: Juliane.Floury@agrocampus-ouest.fr (J. Floury).
}

adaptation to stressful modifications of the cheese matrix, in particular the expression of genes involved in acidic and oxidative stress responses. Still in 2011, Jeanson et al. modelled the spatial distribution of $L$. lactis colonies in model cheese for the first time. Enumerations showed that the final numbers of cells were identical whatever the inoculation level ( $10^{4}$ to $10^{7} \mathrm{CFU} / \mathrm{g}$ ). Bacterial colonies were shown to be randomly distributed, fitting Poisson's model. The initial inoculation level strongly influenced the mean distances between colonies and also their mean diameters. The lower the inoculation level, the larger the colonies were, and the farther away they were from each other. Multiplying the inoculation level by 50 multiplied the interfacial area of exchange with the cheese matrix by 7 for the same cell biomass. How the colonies interact with the curd at a microscopic scale is far from being understood. Nutrients and substrates have to diffuse to reach bacterial colonies, while metabolites have to diffuse from the bacterial colonies into the cheese network. Therefore, the diffusion rates of nutrients and metabolites are probably the limiting factor of the enzymatic activity of microorganism during the ripening process. Floury et al. (2010) reported a strong lack of data about the diffusion properties of key nutrient molecules like sugars, organic acids and peptides in cheese. Until now, only effective diffusion coefficients of small solutes in cheese, like water or salt, were assessed, at a macroscopic scale, using destructive and time-consuming methods. Aly et al. (2011) determined for the first time in ultrafiltrated model cheeses of different compositions an effective diffusion coefficient 
for nisin, a 34-amino-acid peptide, which was about 2-10 times less than salt diffusion coefficients in cheeses. In order to measure the diffusion properties of solutes in cheese, in situ and at the microscopic scale, Floury et al. (2012) adapted the Fluorescence Recovery after Photobleaching (FRAP) technique on a confocal microscope using fluorescent polysaccharides (Fluorescein isothiocyanate (FITC) conjugated dextrans 4 and $20 \mathrm{kDa}$ ) as models of migrant solutes. This study demonstrated that molecules as large as $20 \mathrm{kDa}$ FITC-dextrans (radius $\sim 3.3 \mathrm{~nm}$ ) were able to migrate in cheese, with an effective diffusion coefficient $\sim 3$ times less than in an aqueous solution.

How bacterial colonies, immobilised in cheese, are porous to these diffusing solutes has never been explored. If diffusion limitations of nutrient/metabolite solutes occur around and/or inside the microbial colonies, they may generate gradients of concentration which may alter the metabolic activity of microbial cells, and thus the kinetics of the ripening process. Indeed, in close bacterial cell clustering systems like biofilms, microbial conversions are also controlled by growth kinetics and mass transport processes (deBeer et al., 1997). Diffusion in biofilms and clusters of microorganisms of various compositions has been reported (Briandet et al., 2008; Bryers and Drummond, 1998; Christensen and Characklis, 1990; deBeer et al., 1994, 1997; Guiot et al., 2002; Habimana et al., 2011; Lacroix-Gueu et al., 2005; Libicki et al., 1988; Siegrist and Gujer, 1985; Stewart, 1998; Waharte et al., 2010). It is important to note that most of these studies concern the measurement of the diffusion coefficients of solutes in the overall structure of the biofilm, including both the polysaccharide matrix, voids and the microbial colonies, rather than in the cell clusters only. Moreover, there is little consensus on the values of effective diffusion coefficients of macromolecules in biofilms reported in the literature. Globally, these diffusion coefficients depend mainly on the size and the charge of the migrant molecule, and on the network structure that surrounds the cells, which depends on the bacterial strain studied (deBeer et al., 1997; Takenaka et al., 2009). In voids, both convection and diffusion can occur, whereas in cell clusters molecular diffusion is the sole mechanism responsible for mass transport (deBeer et al., 1994). The objective of this study is to determine if model solutes of different sizes (dextrans from 4.4 to $155 \mathrm{kDa}$ ) are able to penetrate through lactococcus colonies immobilised in a solid matrix like cheese. An L. Lactis subsp. lactis biovar diacetylactis strain of industrial origin exhibiting efficient growth in milk products was used throughout this study (Raynaud et al., 2005; Nouaille et al., 2009; Cretenet et al., 2011). A fat-free cheese made from renneted UF-retentate was used as a model cheese, as described previously by Aly et al. (2011). This UF-model cheese has the great advantage over traditional cheese technology to be moulded after renneting without further syneresis of the gel, and to exhibit highly reproducible microand macro- structural properties. In parallel, the same exploration was performed with lactococcus colonies immobilised in M17-agar, as numerous published studies have used jellified agar media in order to simulate structured food media (Stecchini et al., 2001; Guillier et al., 2006) or soft types of cheese (Aldarf et al., 2004, 2005, 2006; Amrane and Prigent, 2008).

\section{Materials and methods}

\subsection{Bacterial strain and growth conditions}

L. lactis subsp. lactis biovar diacetylactis LD61 was obtained from SOREDAB (Bongrain, La Boissière-Ecole, France) and was routinely grown under static conditions in M17 lactose broth (Difco, Becton Dickinson, Le Pont de Claix, France) at $30{ }^{\circ} \mathrm{C}$. This strain contains plasmids that allow optimal growth in milk from lactose, protease and citrate utilisation (Raynaud et al., 2005).

\subsection{Preparation of the model media}

Ultrafiltered UF-cheese from skim milk was produced as previously described by Aly et al. (2011) and then stored at $-20{ }^{\circ} \mathrm{C}$ in sterile plastic bottles. The total proteins of milk were concentrated 4.8 times and the UF-cheese composition was: dry matter $223 \mathrm{~g} / \mathrm{kg}$, total nitrogen $159.7 \mathrm{~g} / \mathrm{kg}$, non-casein nitrogen $29 \mathrm{~g} / \mathrm{kg}$, and non-protein nitrogen $1.8 \mathrm{~g} / \mathrm{kg}$. The $\mathrm{pH}$ was $6.66( \pm 0.01)$. Before use, the UF-retentate was thawed at $4{ }^{\circ} \mathrm{C}$ overnight and incubated at $48{ }^{\circ} \mathrm{C}$ for $20 \mathrm{~min}$. Then it was stirred and heated up to $93{ }^{\circ} \mathrm{C}$ for $15 \mathrm{~min}$, and immediately placed into a melting ice for $3 \mathrm{~min}$ with manual stirring. This heat treatment led to $98 \%$ denaturation of whey protein that allowed avoiding syneresis of the model cheese by increasing their capacity to retain water in the protein network (Aly et al., 2011). The heat-treated UF-retentate was finally incubated at $30^{\circ} \mathrm{C}$ for $30 \mathrm{~min}$ to reach mineral equilibrium.

Then it was inoculated using a concentration of $10^{5} \mathrm{CFU} / \mathrm{mL}$, and rennet (chymosin with an activity of 180 international milk-clotting units/mL; Maxiren 180; DSM Food Specialities, Delft, The Netherlands) was added at a final concentration of $300 \mu \mathrm{L} / \mathrm{L}$. After homogenization, $1 \mathrm{~mL}$ of the mixture was slowly poured into several mini-gel cassette ${ }^{\circledR}$ systems (IFR Norwich, U.K.) that allow direct observation under the confocal microscope (Floury et al., 2012). They are constituted with an acetate frame $2 \mathrm{~mm}$ thick with an open window of $10 \mathrm{~mm}$ by $10 \mathrm{~mm}$ sealed within a glass slide and a cover slip with two adhesive spacers (Geneframe, ABgene House, UK).

A M17-agar $8 \mathrm{~g} / \mathrm{L}$ based medium was also used as a simpler model of solid food. After sterilisation $\left(121^{\circ} \mathrm{C}, 20 \mathrm{~min}\right), 1 \mathrm{~mL}$ of this medium was cooled down to $40{ }^{\circ} \mathrm{C}$, inoculated with the L. lactis culture using the concentration of $10^{5} \mathrm{CFU} / \mathrm{mL}$ and then immediately poured in the same gel cassette ${ }^{\circledR}$ system.

The gel cassettes ${ }^{\circledR}$ with both media, either the UF-cheese or M17-agar, were then vertically incubated at $30{ }^{\circ} \mathrm{C}$ for $24 \mathrm{~h}$ for coagulation and growth of the L. lactis LD61. In parallel, the two different media were also moulded in sterile sample bottles to measure the $\mathrm{pH}$ during acidification by $L$. lactis. $\mathrm{pH}$ values of the UF-cheese and M17-agar media were respectively 5.80 and 5.40 after $24 \mathrm{~h}$ at $30{ }^{\circ} \mathrm{C}$.

\subsection{Fluorescent dyes and solutes}

LIVE/DEAD ${ }^{\circledR}$ Bacterial Viability Kit (BacLight ${ }^{\mathrm{TM}}$, Molecular Probes, Invitrogen) was applied to estimate both viable and total counts of bacteria in the two M17-agar and UF-cheese model media. The kit is composed of two nucleic acid-binding stains: SYTO $9^{\mathrm{TM}}$ and propidium iodide. SYTO $9^{\mathrm{TM}}$ penetrates all bacterial membranes and stains the cells green, while propidium iodide only penetrates cells with damaged membranes, the combination of the two stains produces red fluorescing cells (Boulos et al., 1999). SYTO $9^{\mathrm{TM}}$ was added before coagulation of the UF-cheese or gelification of the M17-agar to a final concentration of $1.2 \mu \mathrm{mol} / \mathrm{L}$, in order to stain the L. lactis colonies immobilised in the two different media. The propidium iodide was added later, 20 min before microscopic observation, when the colonies had grown in the different matrixes.

Three different sizes of fluorescently labelled dextrans were chosen as a model of migrating solutes to test the porosity of L. lactis colonies in the two model media: Rhodamine B isothiocyanate (RITC) $-4.4 \mathrm{kDa}$, 70 and 155 kDa (Sigma Aldrich, Saint-Quentin Falavier, France). These RITC conjugated dextrans are neutral polymers of anhydroglucose, labelled with an extent of labelling from 0.002 to 0.015 mol RITC per mol glucose. RITC conjugated dextrans $4.4,70$ and $155 \mathrm{kDa}$ have radii of $1.4,6$ and $8.5 \mathrm{~nm}$ respectively (values reported by Sigma-Aldrich; supplier data online). RITC-dextrans were first dissolved to $50 \mathrm{mg} / \mathrm{mL}$ in distilled water, and $10 \mu \mathrm{L}$ of the solution was deposited on the upper side of a gel cassette after growth for $24 \mathrm{~h}$ of L. lactis. The gel cassettes ${ }^{\circledR}$ were then left in the dark in an air-conditioned room at $19{ }^{\circ} \mathrm{C}$ for $3 \mathrm{~h}$ before microscopic observations in order that the dextran molecules could diffuse within the UF-cheese and the M17-agar to a 
depth of several $\mathrm{mm}$. The gel cassettes ${ }^{\circledR}$ containing the M17-agar medium were also observed $6 \mathrm{~h}$ after the deposition of the RITC-dextran solutes on the upper side of the gel. Prior to coagulation of the UF-cheese, Nile blue chloride (Sigma-Aldrich, Germany) could also be added to some samples to a final concentration of $2.8 \mathrm{mmol} / \mathrm{L}$ in order to stain the milk protein network (Auty et al., 2001).

\subsection{Confocal laser scanning microscopy}

Model cheese samples and M17 agar were imaged on an inverted NIKON Eclipse-TE2000-C1si microscope allowing confocal laser scanning microscopy (NIKON-France, Champigny sur Marne, France), with an oil-immersion $60 \times$ objective. Images were acquired at $512 \times 512$ pixel resolution and were scanned approximately at a 10-15 $\mu \mathrm{m}$ distance from the coverslip. SYTO9тM fluorescence was excited with the $488-\mathrm{nm}$ laser and detected between 500 and 530-nm. RITC-dextrans were excited at 543-nm wavelength, and fluorescence emission was detected between 565 and 615-nm. Nile blue was excited with a 633-nm wavelength and fluorescence emission was detected over 650-nm. All experiments were performed at $19{ }^{\circ} \mathrm{C}$ using a temperature-regulated platform and an air-conditioned room and were performed at least in duplicate. For each experiment, a minimum of 5 microscopic observations of different immobilised colonies were acquired per gel cassette.

\section{Results}

\subsection{Confocal laser scanning microscopy of immobilised lactococcus colonies}

In solid matrices such as cheeses or agar, movement of individual cells is restricted leading them to grow as distinctive colonies. As a rule, each final colony is formed from one or very few initial bacteria in case of chain forming bacteria. Fig. 1 shows typical confocal microscopic observation of $L$. lactis LD61 colonies immobilised either in M17-agar (a) or in fat-free UF-cheese (b), after $24 \mathrm{~h}$ of growth at a temperature of $30^{\circ} \mathrm{C}$. With similar growth conditions, colonies of L. lactis have very different shapes depending on the matrix in which they were immobilised. In the agarose based medium, the colonies showed lenticular shapes, while in the fat free UF-cheese, the colonies were perfectly spherical, with diameters ranging between approximately 30 and $50 \mu \mathrm{m}$. Whatever the model media, either the UF-cheese or M17-agar, the LIVE/DEAD fluorescent staining method showed that all bacterial cells were still alive after 24 h growth, whereas only about 2 or 3 cells maximum per colony were dead after $48 \mathrm{~h}$. Cretenet et al. (2011) showed that the growth of L. lactis LD61 stopped after $24 \mathrm{~h}$, but $L$. lactis remained viable and metabolically active up until 7 days in UF-cheese.
In order to observe the distribution of the milk proteins within L. lactis colonies, Nile blue was added before coagulation of the UF-cheese to stain all the proteins. Fig. 2 shows that no fluorescence is detected by confocal microscopy in between the cells within the colony indicating a total absence of proteins around the bacteria. Therefore, the space between the lactococcus cells within a colony is likely to be composed mainly of the serum phase of the UF-cheese.

\subsection{Porosity of colonies}

A specific experimental design was created to determine if solutes are able to penetrate within the colonies: solutions of fluorescent dextrans 4.4, 70 and $155 \mathrm{kDa}$ were deposed on the upper side of a gel cassette ${ }^{\circledR}$ filled either with M17-agar or UF-cheese, both previously inoculated with L. lactis LD61 and incubated in the same way. The gel cassettes were then directly observed by confocal laser microscopy after $3 \mathrm{~h}$ of diffusion of the fluorescent tracers at $19{ }^{\circ} \mathrm{C}$ (Fig. 3). In parallel, the corresponding relative fluorescence intensity profiles within the colony versus in the surrounding media, either M17-agar or UF-cheese, were quantified. The gel cassettes ${ }^{\circledR}$ containing the M17-agar gel were also observed after $6 \mathrm{~h}$ of diffusion to evaluate the aspect of time on the penetration rates of the dextran solutes inside the colonies (Fig. 4). Fig. 3 shows that after $3 \mathrm{~h}$ of diffusion, penetration of the three different RITC-dextrans (in red) is obvious in both media, whatever the size of the solute. However, those results are much more contrasted between the UF-cheese and the M17agar if we look at the relative fluorescence intensity profiles, which allow in situ quantification of the diffusing solute concentrations inside the colonies. The black zones visualised inside a colony correspond to the $L$. lactis cells, confirming that they do not have incorporated fluorescent dextran molecules within their cytoplasm. In both media, RITCdextran $4.4 \mathrm{kDa}$ can be visualised inside the colony, everywhere around the L. lactis cells (Fig. 3a), with a relative similar intensity of fluorescence: around $50 \%$ to $60 \%$ of the surrounding fluorescence out of the colony. This means that a non-negligible proportion of RITC-dextran $4.4 \mathrm{kDa}$ molecules can diffuse inside the immobilised L. lactis colonies. It was also noted that the fluorescence intensity profile is flatter in the agarose gel than in the UF-cheese. On Fig. 3b and c, RITC-Dextran $70 \mathrm{kDa}$ and RITC-Dextran $155 \mathrm{kDa}$ were clearly visualised within the colonies in the UF-cheese after $3 \mathrm{~h}$ of migration, but not within the colonies immobilised in the M17-agarose gel after the same investigation time. These observations were confirmed by the quantification of the relative fluorescence intensity inside the immobilised colonies, which was in both cases much lower in agarose (around 20\% of the fluorescence intensity out of the colony) than in the UF-cheese (around 60\%). Moreover, for both sizes of RITC-dextran molecules (70 and $155 \mathrm{kDa}$ ), the fluorescent profiles were quite flat inside the colonies immobilised in agarose whereas



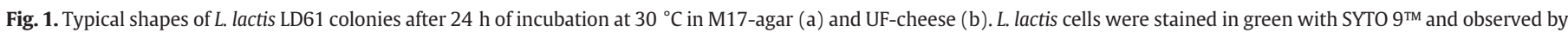
confocal laser scanning microscopy. (For interpretation of the references to colour in this figure legend, the reader is referred to the web version of this article.) 

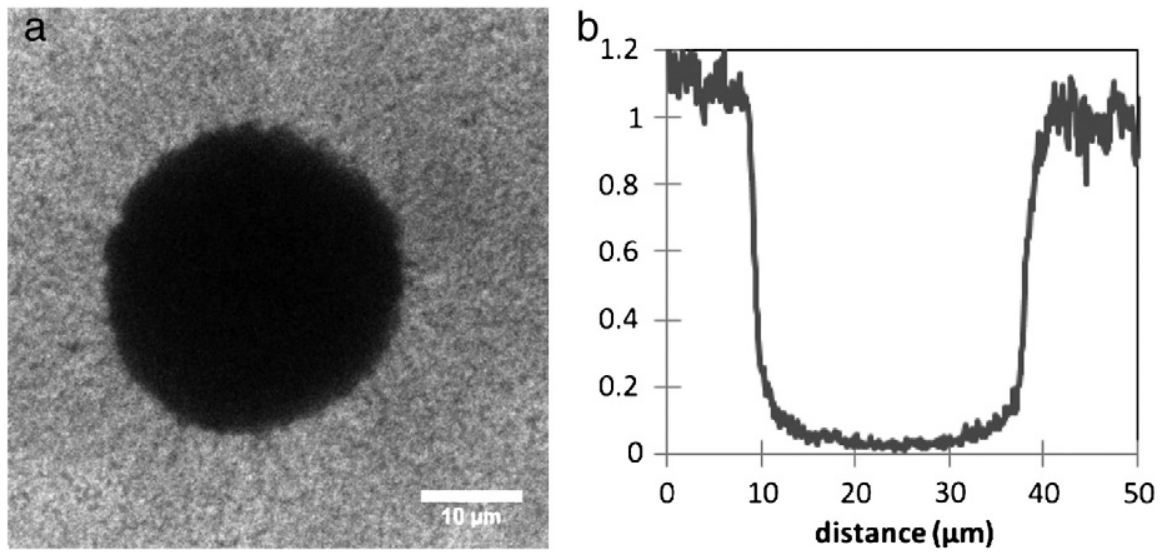

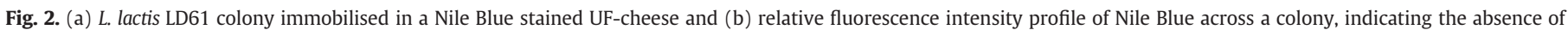
proteins around bacterial cells composing the colony.

they are very irregular in the colonies immobilised in the UF-cheese. From the observation of the colonies immobilised in the M17-agar medium $6 \mathrm{~h}$ after the deposition of RITC-dextran at the surface of the gel, we showed by graphically reporting the radial relative fluorescent intensity inside the colonies (Fig. 4) that the concentration of RITC-dextran reached the same level inside the colonies whatever the size of the
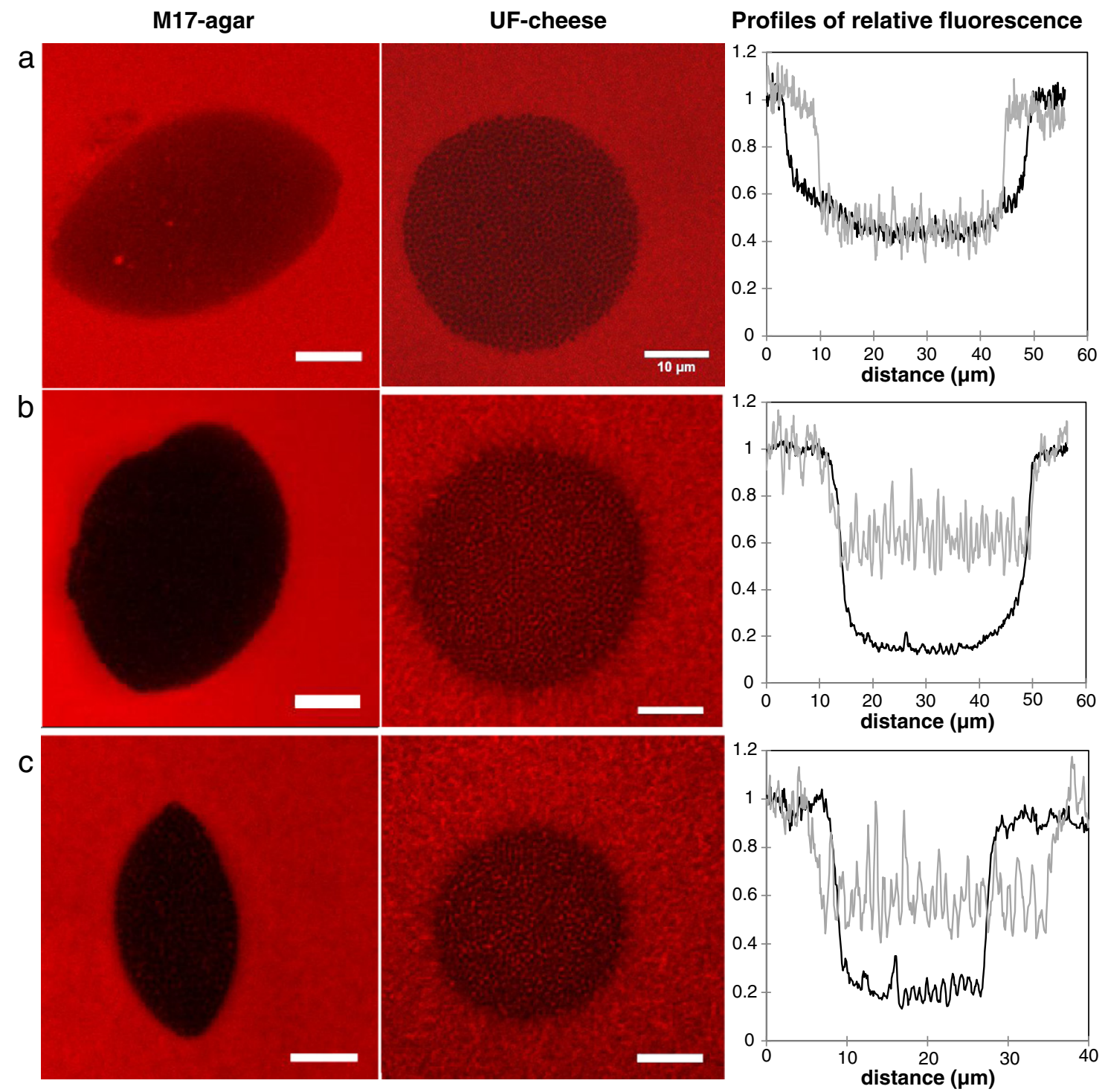

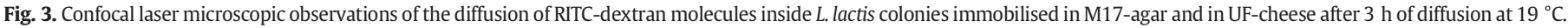

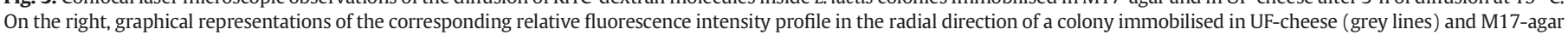
(black lines). (a) RITC-dextran 4.4 kDa, (b) RITC-Dextran $70 \mathrm{kDa}$ and (c) RITC-Dextran $155 \mathrm{kDa}$. Scale bars correspond to $10 \mu \mathrm{m}$. 


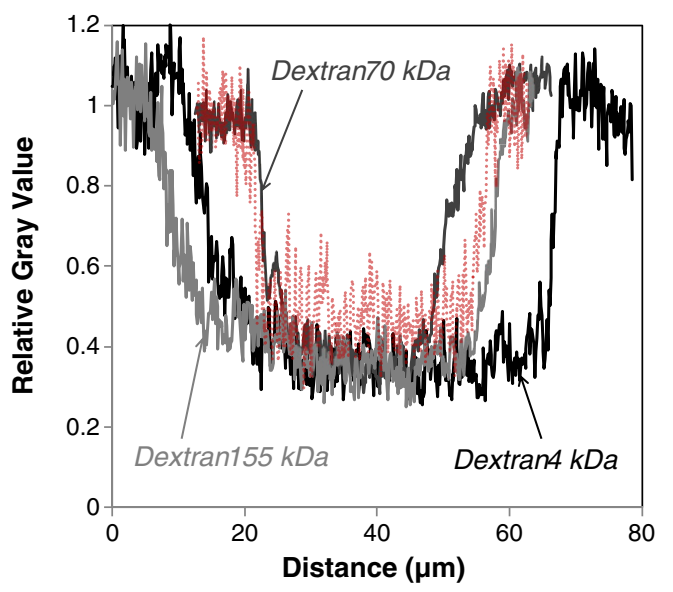

RITC-Dextran 4kDa in UF-cheese after $24 \mathrm{~h}$ of diffusion

Fig. 4. Relative fluorescence intensity profile obtained from confocal laser microscopic observations of RITC-dextrans 4.4, $70155 \mathrm{kDa}$ inside L. lactis colonies immobilised in M17-agar after $6 \mathrm{~h}$ of diffusion at $19{ }^{\circ} \mathrm{C}$. The red dotted line corresponds to the relative fluorescence intensity of RITC-dextran $4 \mathrm{kDa}$ inside L. lactis colonies immobilised in UF-cheese after $24 \mathrm{~h}$ of diffusion at $19{ }^{\circ} \mathrm{C}$.

dextran. The fluorescent intensity was then around $60 \%$ the fluorescence intensity out of the colony, which in fact corresponds to the value obtained after $3 \mathrm{~h}$ of migration in the UF-cheese (Fig. 4). Therefore, in addition to the physico-chemical properties of the diffusing solute, the aspect of time seems to be also very influential on the penetration rate of solutes inside colonies immobilised in solid media such as agar gel or model cheese. It can be concluded that lactococcus colonies immobilised in M17 agar or in UF-cheese are porous to dextrans from $4 \mathrm{kDa}$ to $155 \mathrm{kDa}$, but the diffusion rates of the highest molecular weight dextrans (70 and $155 \mathrm{kDa}$ ) are higher in the UF-cheese than in the agarose gel.

\section{Discussion}

In solid matrices such as cheese or agar, cells grow as separate individual colonies. As a rule, each colony is formed from one bacterium and the final number of colonies is defined by the inoculation level (Wimpenny et al., 1995). Jeanson et al. (2011) have recently shown that the distribution of lactococcus colonies was random in ultrafiltered model cheeses. In the present study, the colonial shape of the same strain was shown to be lenticular in M17-agar gel and perfectly spherical in UF model cheeses. This would indicate that the physical pressure exerted on the colony was isotropous in the UF-cheese but not in agar. Mitchell and Wimpenny (1997) investigated the effect of agar concentration on the growth and morphology of submerged bacterial colonies of several species in agar gels. They observed lenticular colonies for all species, except with Bacillus cereus, at high agar concentrations $(>6.5 \mathrm{~g} / \mathrm{L})$. At lower agar concentrations, non-motile organisms were grown as small lobed to diffuse spherical colonies. Kabanova et al. (2012) also observed colonies of L. lactis IL1403 with lenticular shapes when inoculated in agar at different inoculation levels. Agar consists of a mixture of linear galactans. Hydrogen bonding between agarose molecules is responsible for gel networking, which is thought to be stabilised by structured water (Watase and Nishinari, 1986). As cooling progresses, helices are formed which aggregate to form a gel network (SanBiagio et al., 1996). Agar is known to form a very porous gel with an average pore size varying with concentration and type of agarose, typically between 100 and $300 \mathrm{~nm}$ (Griess et al., 1989). When bacteria are starting to multiply in this solid media, they are forming colonies in the pores of agar gel, overcoming the resistance of the media by breaking the bonds between the chains of polysaccharides and thus "enlarging" pores (Pernodet et al., 1997). For Mitchell and Wimpenny (1997), in lenticular colonies, the agar may split along a particular fault line due to the hydrostatic pressure exerted by the bacterial growth. The agar remained compressed in the centre of the structure leading to the formation of the characteristic lens or discus-shaped structure. They also demonstrated by transmission electron microscopy that the cells were densely packed in the lenticular colonies immobilised in agar gels.

In fat-free UF-cheese, the resistance of the surrounding casein network may be lower and/or perfectly isotropous to allow bacteria to form spherical colonies. Indeed, Saboya (2002) compared the protein networks of UF-cheese cheese versus traditional cheese by scanning electron microscopy. Her microstructural observations showed an extreme regularity of the protein network of the UF-cheese, while the network of the traditional cheese seemed to be much more chaotic. We can then reasonably make the assumption that the strength exerted toward the colonies by the solid matrix is isotropous in the case of fat-free UF-cheese but not in the case of agar gel. In cheese containing fat globules, either full fat UF-cheese (unpublished observations) or traditional cheese (Laloy et al., 1996; Lopez et al., 2006), bacterial colonies were not spherical anymore. Laloy et al. (1996) reported that the microstructural and physicochemical dynamics of fat globules in cheese appear to influence the localization and retention of bacteria in cheese. Using electron microscopy, the authors localised the bacteria on the periphery of fat globules. Lopez et al. (2006) showed by confocal microscopy that colonies of lactococcus bacteria were preferentially localised at the fat/casein interface. The bacteria were mainly dispersed in the whey pockets surrounding a fat inclusion. In traditional cheese technology, during the formation of the rennet-induced casein network, bacteria may be forced out of the protein matrix and thus expelled in pockets of whey surrounding fat inclusions, where they grew and became entrapped at the fat/protein interface. Therefore, for cheese technology based on ultrafiltered milk, where the draining phase is avoided, we can make the assumption that colonies are not spherical anymore because the fat leads to a more anisotropic constraint exerted in situ by the media toward colonial growth, either by direct interaction/affinity with bacteria and/or by disturbing the casein network regularity. In the fat-free UF-cheese used in this work, the absence of any casein or whey proteins particles inside the colony (complete absence of blue nile staining) indicates that the serum phase within the colony of $L$. lactis was mainly composed of water, lactose and minerals (Fig. 2). Indeed, the UF-cheese network used in this study is mainly composed of casein micelles, heat-induced aggregates of $\alpha$-lactalbumin and $\beta$-lactoglobulin and serum phase (lactose, minerals and free amino acids). Whey protein aggregates were formed during the drastic heat treatment $\left(93^{\circ} \mathrm{C} / 15 \mathrm{~min}\right.$ ) applied to the UF-retentate before coagulation. During the heat treatment, these particles also tend to non-covalently bind to casein micelles (Guyomarc'h et al., 2003). Cheese is a very particular medium, in which the use of caseins as amino acid sources and for growth requires functional extracellular proteases, oligopeptide transporters and intracellular peptidases (Raynaud et al., 2005; Cretenet et al., 2011). During cheese ripening, free amino acids available nearby $L$. lactis LD61 colonies are probably consumed by the bacteria until the concentration of this nutrient become limiting for their growth. Cretenet et al. (2011) showed that the cell wall protease activity of $L$. lactis immobilised as colonies was still active after 7 days in UF-cheeses. It might though hydrolyse the casein micelles composing the cheese network. The fact that even the whey proteins, which are known not to be hydrolysed by lactic acid bacteria are totally absent inside a colony suggests that the colonies must probably push the protein network around them when growing, by consuming the caseins available nearby.

Whatever their shape, how bacterial colonies immobilised in cheese are porous to model solutes such as dextran molecules was explored here for the first time. If diffusion limitations of nutrients, metabolites and enzymes occur around, and/or inside the microbial colonies, they may generate gradients of concentration which may alter the metabolic activity of microbial cells, and thus the kinetics of the ripening process. 
From this work, it can be concluded that lactococcus colonies immobilised in M17-agar or in UF-cheese are porous to dextrans from $4 \mathrm{kDa}$ to $155 \mathrm{kDa}$. However, the kinetic of diffusion of the dextran molecules inside the colonies depends on the media in which they are immobilised. Indeed, $3 \mathrm{~h}$ after the deposition of the diffusing solutes at the surface of each model medium, the relative fluorescence intensity of the highest molecular weight dextrans $(\geq 70 \mathrm{kDa})$ within the colony was three times higher in the UF-cheese than in M17-agar, whereas it reached the same level in both media after $6 \mathrm{~h}$ of diffusion (Figs. 3 and 4). This would indicate that either the kinetic of dextran diffusion within the colony, or the composition/organisation of the interface between the colony and the matrix, is different in both media, more limiting in the case of the agar medium. Indeed, the signals of fluorescence intensity within colonies immobilised in UF-cheese were spatially much more irregular than in agarose, such as large dextran molecules were penetrated into the colonies by forming canal-like structures facilitating their way through the cells. The existence of these canal-like structures could be coherent with the dark zones observed all around colonies in the casein network of UF-cheese, clearly visible on Fig. $3 b$ and c. However, manual counting of the number of cells detected in a focal plane of a colony immobilised, either in UF-cheese or in M17-agar gel, did not allow any significant difference to be revealed in the packing density of the cells between the two media $\left(\sim 0.7 \pm 0.2 \mathrm{cell} / \mu^{2}\right)$. Observations at smaller scale, using transmission electron microscopy, would be interesting in order to explore more precisely the space between bacterial cells, as well as the interface between lactococcus colonies and the matrix.

The fact that some molecules as large as $155 \mathrm{kDa}$ dextrans are able to penetrate into the bacterial colonies immobilised in a solid medium like cheese calls into question the existence of a possible restriction of the metabolic activity of these bacteria by some diffusion limitation phenomena. The diffusion rates of these fluorescently labelled dextrans of different sizes should now be quantified more precisely to assess to what extent kinetics of penetration of these model solutes are dependent on their size. For that purpose, the experimental techniques commonly used since the late 1990s for diffusion assays throughout biofilms are based on confocal microscopy, by studying the rate of penetration of fluorescent solutes of different sizes (Thurnheer et al., 2003), or by application of dynamic techniques such as FRAP and FCS (Fluorescence Correlation Spectroscopy) (Lawrence et al., 1994; Waharte et al., 2010; Zhang et al., 2011). All these studies conclude that whatever the bacterial species present, the tracer diffusion of solutes is slowed down in the biofilm compared to a free diffusion in an aqueous solution, due to the presence of the network that surrounds the bacterial colonies. Two recent studies (Rani et al., 2005; Takenaka et al., 2009) are closer to the configuration that interests us, namely to characterise the diffusion of solutes within clusters of microbial cells. Rani et al. (2005) directly visualised the diffusive penetration of two antibiotic-sized tracer molecules into staphylococcal biofilm cell clusters, non-invasively and in real time. This was accomplished by using fluorescent dyes (rhodamine B and fluorescein, MW 400 Da) that were imaged by confocal scanning laser microscopy. Quantitative image analysis was performed to extract numerical values of the effective diffusion coefficient in the biofilm by approximating cell clusters as hemispheres. These two fluorescent tracers saturated the interior of cell clusters within a few minutes. Takenaka et al. (2009) developed an original technique called time-lapse CSLM to visualise the diffusive penetration of fluorescently tagged macromolecules into three different species of biofilms formed by oral microorganisms grown in a flow cell. The diffusive penetration time was quantified as the time required to attain $90 \%$ of the equilibrium fluorescence intensity at the centre of a biofilm cell cluster. They showed that a small solute, such as fluorescein, diffuses into the centre of the cluster faster than a larger solute does, such as dextran ( $3 \mathrm{kDa})$. However, none of the macromolecules investigated in this study, including the largest, IgG $(\sim 150 \mathrm{kDa})$, failed to reach the centre of microbial cell clusters that were approximately a few hundred micrometres in diameter. These data led to the conclusion that cell cluster in biofilm also, and not only the extracellular matrix, is porous to large macromolecules, which is similar to what we observed in cheese, supporting the hypothesis of common points between physiology in biofilm and in colonies immobilised in cheese matrix.

To conclude, the porosity toward high molecular weight dextrans of colonies of L. lactis LD61 immobilised in UF-cheese was demonstrated here for the first time, which would indicate that molecules like enzymes or large substrates can diffuse inside and outside of the colony. Results reported here provide a platform for further work on diffusion phenomena inside immobilised colonies: (i) The inoculation levels of L. lactis LD 61 in UF-cheese should be tested in order to evaluate the effect of the size of the colonies on the rate of penetration of model solutes like RITC-dextrans; (ii) Porosity of L. lactis colonies to other solutes, more representatives of real substrates and nutrients than dextran polymers, should be tested; (iii) In order to assess if the porosity of colonies also depends on bacterial surface properties, other species of lactic acid bacteria and other bacterial strains should be tested; and (iv) Other cheese matrix composition and microstructure should also be investigated to fully understand the interaction between the bacteria and the cheese network, and to finally get a deeper understanding of the ripening process.

\section{References}

Aldarf, M., Fourcade, F., Amrane, A., Prigent, Y., 2004. Diffusion of lactate and ammonium in relation to growth of Geotrichum candidum at the surface of solid media. Biotechnology and Bioengineering 87, 69-80.

Aldarf, M., Fourcade, F., Amrane, A., 2005. Solid-state culture of Geotrichum candidum and Penicillium camembertii on a glutamate and lactate based medium. Enzyme and Microbial Technology 36, 159-167.

Aldarf, M., Fourcade, F., Amrane, A., Prigent, Y., 2006. Substrate and metabolite diffusion within model medium for soft cheese in relation to growth of Penicillium camembertii. Journal of Industrial Microbiology and Biotechnology 33, 685-692.

Aly, S., Floury, J., Famelart, M.H., Madec, M.N., Dupont, D., Le Gouar, Y., Lortal, S., Jeanson, S., 2011. Nisin Quantification by ELISA allows the modeling of its apparent diffusion coefficient in model cheeses. Journal of Agricultural and Food Chemistry 59, 9484-9490.

Amrane, A., Prigent, Y., 2008. Diffusion of calcium and inorganic phosphate at the surface of a solid model medium in relation with growth of Geotrichum candidum and Penicillium camembertii. Journal of Food Biochemistry 32, 813-825.

Auty, M.A.E., Twomey, M.Y.R.A., Guinee, T.P., Mulvihill, D.M., 2001. Development and application of confocal scanning laser microscopy methods for studying the distribution of fat and protein in selected dairy products. The Journal of Dairy Research 68, 417-427.

Boulos, L., Prévost, M., Barbeau, B., Coallier, J., Desjardins, R., 1999. LIVE/DEAD® BacLight ${ }^{\mathrm{TM}}$ : application of a new rapid staining method for direct enumeration of viable and total bacteria in drinking water. Journal of Microbiological Methods 37, 77-86.

Briandet, R., Lacroix-Gueu, P., Renault, M., Lecart, S., Meylheuc, T., Bidnenko, E., Steenkeste, K., Bellon-Fontaine, M., Fontaine-Aupart, M.-P., 2008. Fluorescence correlation spectroscopy to study diffusion and reaction of bacteriophages inside biofilms. Applied and Environmental Microbiology 74, 2135-2143.

Bryers, J.D. Drummond, F. 1998. Local macromolecule diffusion coefficients in structurally non-uniform bacterial biofilms using fluorescence recovery after photobleaching (FRAP). Biotechnology and Bioengineering 60, 462-473.

Christensen, B.E., Characklis, W.G., 1990. Physical and chemical properties of biofilms. In: Characklis, W.G., Marshall, K.C. (Eds.), Biofilms. John Wiley \& Sons, New York, p. 93-130.

Cretenet, M., Laroute, V., Ulve, V., Jeanson, S., Nouaille, S., Even, S., Piot, M., Girbal, L., Le Loir, Y., Loubiere, P., Lortal, S., Cocaign-Bousquet, M., 2011. Dynamic analysis of the Lactococcus lactis transcriptome in cheeses made from milk concentrated by ultrafiltration reveals multiple strategies of adaptation to stresses. Applied and Environmental Microbiology 77, 247-257.

deBeer, D., Stoodley, P., Roe, F., Lewandowski, Z., 1994. Effects of biofilm structures on oxygen distribution and mass-transport. Biotechnology and Bioengineering 43, 1131-1138.

deBeer, D., Stoodley, P., Lewandowski, Z., 1997. Measurement of local diffusion coefficients in biofilms by microinjection and confocal microscopy. Biotechnology and Bioengineering 53, 151-158.

Floury, J., Jeanson, S., Aly, S., Lortal, S., 2010. Determination of the diffusion coefficients of small solutes in cheese: a review. Dairy Science \& Technology 90, 477-508.

Floury, J., Madec, M.N., Waharte, F., Jeanson, S., Lortal, S., 2012. First assessment of diffusion coefficients in model cheese by fluorescence recovery after photobleaching (FRAP). Food Chemistry 133, 551-556

Griess, G.A., Moreno, E.T., Easom, R.A., Serwer, P., 1989. The sieving of spheres during agarose gel electrophoresis: quantitation and modeling. Biopolymers 28, 1475-1484.

Guillier, L., Pardon, P., Augustin, J.C., 2006. Automated image analysis of bacterial colony growth as a tool to study individual lag time distributions of immobilised cells. Journal of Microbiological Methods 65, 324-334. 
Guiot, E., Georges, P., Brun, A., Fontaine-Aupart, M.P., Bellon-Fontaine, M.N., Briandet, R., 2002. Heterogeneity of diffusion inside microbial biofilms determined by fluorescence correlation spectroscopy under two-photon excitation. Photochemistry and Photobiology 75, 570-578.

Guyomarc'h, F., Law, A.J.R., Dalgleish, D.G., 2003. Formation of soluble and micellebound protein aggregates in heated milk. Journal of Agricultural and Food Chemistry $51,4652-4660$.

Habimana, O., Steenkeste, K., Fontaine-Aupart, M.-P., Bellon-Fontaine, M.-N., Kulakauskas, S., Briandet, R., 2011. Diffusion of nanoparticles in biofilms is altered by bacterial cell wall hydrophobicity. Applied and Environmental Microbiology 77, 367-368.

Jeanson, S., Chadoeuf, J., Madec, M.N., Aly, S., Floury, J., Brocklehurst, T.F., Lortal, S., 2011. Spatial distribution of bacterial colonies in a model cheese. Applied and Environmental Microbiology 77, 1493-1500.

Kabanova, N., Stulova, I., Vilu, R., 2012. Microcalorimetric study of the growth of bacterial colonies of Lactococcus lactis IL1403 in agar gels. Food Microbiology 29, 67-79.

Lacroix-Gueu, P., Briandet, R., Leveque-Fort, S., Bellon-Fontaine, M.N., Fontaine-Aupart, M.P., 2005. In situ measurements of viral particles diffusion inside mucoid biofilms. Comptes Rendus Biologies 328, 1065-1072.

Laloy, E., Vuillemard, J.C., ElSoda, M., Simard, R.E., 1996. Influence of the fat content of Cheddar cheese on retention and localization of starters. International Dairy Journal $6,729-740$.

Lawrence, J.R., Wolfaardt, G.M., Korber, D.R., 1994. Determination of diffusion-coefficients in biofilms by confocal laser microscopy. Applied and Environmental Microbiology $60,1166-1173$.

Libicki, S.B., Salmon, P.M., Robertson, C.R., 1988. The effective diffusive permeability of a nonreacting solute in microbial cell aggregates. Biotechnology and Bioengineering 32, 68-85.

Lopez, C., Maillard, M.-B., Briard-Bion, V., Camier, B., Hannon, J.A., 2006. Lipolysis during ripening of Emmental cheese considering organization of fat and preferential localization of bacteria. Journal of Agricultural and Food Chemistry 54 (16), 5855-5867.

Mitchell, A.J., Wimpenny, J.W.T., 1997. The effects of agar concentration on the growth and morphology of submerged colonies of motile and non-motile bacteria. Journal of Applied Microbiology 83, 76-84.

Nouaille, S., Even, S., Charlier, C., Le Loir, Y., Cocaign-Bousquet, M., Loubiere, P., 2009. Transcriptomic response of Lactococcus lactis in mixed culture with Staphylococcus aureus. Applied and Environmental Microbiology 75 (13), 4473-4482.

Pernodet, N., Maaloum, M., Tinland, B., 1997. Pore size of agarose gels by atomic force microscopy. Electrophoresis 18, 55-58.
Rani, S.A., Pitts, B., Stewart, P.S., 2005. Rapid diffusion of fluorescent tracers into Staphylococcus epidermidis biofilms visualised by time lapse microscopy. Antimicrobial Agents and Chemotherapy 49, 728-732.

Raynaud, S., Perrin, R., Cocaign-Bousquet, M., Loubiere, P., 2005. Metabolic and transcriptomic adaptation of Lactococcus lactis subsp lactis biovar diacetylactis in response to autoacidification and temperature downshift in skim milk. Applied and Environmental Microbiology 71 (12), 8016-8023.

Saboya, L.V., 2002. Lise de Lactococcus sp. e proteolise em queijos fabricados com ultrafiltraçao e microfiltraçao. Escola Superior de Agricultura Luiz de Queiroz. Thesis/ Dissertation. (203 pp.).

SanBiagio, P.L., Bulone, D., Emanuele, A., PalmaVittorelli, M.B., Palma, M.U., 1996 Spontaneous symmetry-breaking pathways: time-resolved study of agarose gelation. Food Hydrocolloids 10, 91-97.

Siegrist, H., Gujer, W., 1985. Mass-transfer mechanisms in a heterotrophic biofilm. Water Research 19, 1369-1378.

Stecchini, M.L., Del Torre, M., Donda, S., Maltini, E., Pacor, S., 2001. Influence of agar content on the growth parameters of Bacillus cereus. International Journal of Food Microbiology 64, 81-88.

Stewart, P.S., 1998. A review of experimental measurements of effective diffusive permeabilities and effective diffusion coefficients in biofilms. Biotechnology and Bioengineering 59, 261-272.

Takenaka, S., Pitts, B., Trivedi, H.M., Stewart, P.S., 2009. Diffusion of macromolecules in model oral biofilms. Applied and Environmental Microbiology 75, 1750-1753.

Thurnheer, T., Gmur, R., Shapiro, S., Guggenheim, B., 2003. Mass transport of macromolecules within an in vitro model of supragingival plaque. Applied and Environmental Microbiology 69, 1702-1709.

Waharte, F., Steenkeste, K., Briandet, R., Fontaine-Aupart, M.-P., 2010. Diffusion measurements inside biofilms by image-based fluorescence recovery after photobleaching (FRAP) analysis with a commercial confocal laser scanning microscope. Applied and Environmental Microbiology 76, 5860-5869.

Watase, M., Nishinari, K., 1986. Rheological and thermal-properties of polysaccharide gels extracted from Ahnfeltia-plicata. Colloid \& Polymer Science 264, 877-882.

Wimpenny, J.W.T., Leistner, L., Thomas, L.V., Mitchell, A.J., Katsaras, K., Peetz, P., 1995 Submerged bacterial colonies within food and model systems: their growth, distribution and interactions. International Journal of Food Microbiology 28, 299-315.

Zhang, Z., Nadezhina, E., Wilkinson, K.J., 2011. Quantifying diffusion in a biofilm of Streptococcus mutans. Antimicrobial Agents and Chemotherapy 55, 1075-1081. 